\title{
WAR Metaphors in Indonesian-English Political Discourse
}

\author{
Norita Purba \\ Applied Linguistics Department \\ Yogyakarta State University \\ Yogyakarta, Indonesia \\ noritapurba1993@outlook.com
}

\author{
Sufriati Tanjung \\ Applied Linguistics Department \\ Yogyakarta State University \\ Yogyakarta, Indonesia \\ sufriyati@uny.ac.id
}

\begin{abstract}
This study is aimed at identifying WAR metaphors in Indonesian political discourse and their translation into English. The data were obtained from Tempo Magazine, during January to March 2018, with 29 political articles covering the political elections of 2018 and 2019. To discover the concept of metaphor, this study applied Conceptual Metaphor Theory (CMT) proposed by Lakoff and Johnson (1980). Metaphor Identification Procedure (MIP), formulated by Pragglejaz Group (2007), was used in this study to avoid intuition during metaphor identification. This study found that WAR metaphor was positively pervasive in Indonesian political discourse. There were 49 metaphorical war expressions with total 239 occurances. A cross-mapping from war domain to politics domain were soldier to political candidate, war strategy to campaign strategy, battleground to political elections, target to power, alliance to parties coalition, and weapon to votes. The conceptual mapping highlights politics as a battle for power and hides politics as an attempt to proper people. The implemented strategies in the transslation were 162 by providing the same metaphors, 29 by providing a different metaphor, 40 by providing literal paraphrases, and 8 by omiting the metaphors.
\end{abstract}

Keywords-conceptual metaphor; WAR metaphor; translation strategy; political discourse

\section{INTRODUCTION}

Metaphor has been widely discussed in several studies such as linguistic, communication, and translation. Metaphor is a way of communication which reflects how people think and act. Metaphor is used in various patterns of discourse since it is believed that metaphor is a powerful tool to achieve the persuasive, poetic, and informative language function. Metaphor is commonly viewed from two different perspectives, namely linguistic perspective and cognitive perspective.

The linguistic perspective is often called as the traditional view of metaphor in which metaphor is usually defined as the figurative expressions used in the literature texts to achive poetic language function. Meanwhile, cognitive perspective is a new approach to study metaphor by considering the human cognitive system. This perspective was firstly introduced by cognitive linguists Lakoff and Johnson [1] in their work Metaphor We Live By. They called this as Conceptual Metaphor Theory (CMT). This theory rejects the perspective that metaphor is only used in literature texts. Instead, this teory holds that metaphor is pervasive in everyday life, not only in language but also in thought and action.

One of the most common conceptual metaphor in human cognitive is WAR metaphor. It has been used widely to structure various activities of human life such as politics, argument, economics, and competition. The use of the concept of war in argument is reflected by the expressions such as "Your claims are indefensible", "He attacked every weak point in my argument", and "His criticisms were right on the target". The words indenfensible, attack, and target are the lexical items or expressions of war domain. Argument is conceptualized as a war in which one argues with an opponent, he can win or lose, he struggles to defend his position, he attackes opponent's posisition and he uses strategy to win. WAR metaphors in the sentences are not merely as figurative speech but they reflect how people think and act in agument.

\section{REVIEW OF LITERATURE}

\section{A. Conceptual Metaphor Theory}

Conceptual Metaphor Theory (CMT) was initially introduced by Lakoff and Johnson in 1980 as a new approach in the study of metaphor. They proposed this theory to reject the perspective that metaphor is only used in literature texts. Instead, they believe that metaphor is pervasive in everyday life, not only in language but also in thought and action. The impression of conceptual metaphor is understanding and experiencing one thing in term of another. Life consists of numerous abstract and complex concepts which are not understood by all people. Therefore, the abstract and complex concepts are often described using another concept which is more concrete and familiar to people.

Lakoff and Johnson [1, pp. 14-32] divide metaphors into three categories: orientational metaphor, and ontological metaphor, and structural metaphor. Orietational metaphor describes the concept of spatial orientation, such as up-down, front-back, in-out, deep-shallow, on-off, central-peripheral, e.g. happy is up; sad is down,which can be recognized from sentences such as I'm feeling up, I'm in high spirit, I'm feeling down, I'm depressed. Ontological metaphor describes human experiences as physical entities. There are two types of ontological metaphor, namely human entity, e.g. Our biggest 
enemy right now is inflation and non-human entity, e.g. Life has cheated me. Structural metaphor describes the stucture of one concept in the structures of another concept, e.g. Time is money.

In the discussion of metaphor, Lakoff and Johnson introduce several terms to describe the mechanism of how metaphorical meaning is created namely source domain, target domain, and mapping. Based on this theory, metaphors are linguistic expressions of cross-domain mappings occur in thought, from source domain to the target domain. Source domain is the conceptual domain the metaphorical expression are drawn from. Target domain is the domain which people try to understand. Mapping is the correspondences between source domain and target domain. The table below is te example of the mapping of conceptual metaphor LOVE IS JOURNEY.

TABLE I. CONCEPTUAL MAPPING OF METAPHOR LOVE IS JOURNEY

\begin{tabular}{|l|l|}
\hline \multicolumn{1}{|c|}{ Source Domain (Journey) } & \multicolumn{1}{c|}{ Target Domain (Love) } \\
\hline Travelers & The lovers \\
\hline The vehicle & The love relationship itself \\
\hline The journey & Events in the relationship \\
\hline The distance covered & The progress made \\
\hline The obstacle encountered & The difficulties experienced \\
\hline Decisions about which way to go & Choices about what to do \\
\hline The destination of the journey & The goal of relation ship \\
\hline
\end{tabular}

The table above shows the mechanism of how the conceptual metaphor LOVE IS JOURNEY is structured. The concept of love sometimes is difficult to describe so it often conceptualized by the concept of journey. The mappings occur from several aspects of journey to the aspects of love to provide a more concrete description of love.

There are two others terms in the discussion of conceptual metaphor namely hiding and highlighting. In understanding one thing in terms of another, there will be some aspects to be hid and other aspects to be highlighted. The conceptual metaphor LOVE IS JOURNEY highlights that love is a long journey in which the lovers can experience good and bad experiences, but the metaphor hides that love is between two hearts which share feelings each other.

Any word can be a metaphor and to examine whether the word is metaphrical or not, the word must be matched with its primary or literal meaning [2]. According to Zheng [3, p. 134] in the view of modern metaphor theory, abnormal collocations in form and conflict in semantic meaning are metaphors. Comprehending metaphor is the conceptual processes in which a translator maps the correspondence properties between source domain and target domain. Pragglejaz Group [4] formulated a set of instruction of metaphor identification called Metaphor Identification Procedure (MIP). This tool was created since there was no scholar which provide empirical criteria of metaphor. MIP moves away metaphor identification from intuition to achieve the reliability of metaphor. Pragglejaz Group [4, p. 3] explains the MIP steps as following.
- Reading the text-discourse to establish a general understanding of the meaning

- Determining the lexical units in the text-discourse. For each lexical unit in the text, establish its meaning in context, that is, how to apply it to an entity, relation, or attribute in the situation evoked by the text (contextual meaning). Take into account what comes before and after the lexical unit. For each lexical unit, determine if it is has a more basic contemporary meaning in other context than the one in the given context.

- If the lexical unit has a more basic currentcontemporary meaning in other contexts than the given context, decide whether the contextual meaning contrast with the basic meaning but can be understood in comparison with it.

- If yes, mark the lexical unit as metaphorical.

\section{B. Metaphor in Political Discourse}

Language is one of the most powerful tools in politics since politics is planned, organized, and realized using language. Language of politics simultaneously delivers two language functions namely informative function and persuasive function. Language is not only used to inform people about parliamentary or presidential candidate's job programs, but it implicitly also attempts to gain voters. Employing metaphors is an effective strategy to create a powerful political speech. Xu [5, pp. 397-402] found that metaphors contribute in creating a brief, clear, and meaningful political speech and serve to guide public perception, provide new insight and experience, and simplify the way of informing people by stirring their emotions.

Otieno, Owino \& Attyang [6, pp. 21-26] reviewed seven studies on metaphor in political discourses and found that metaphors were pervasive to the discourse. Several source domains from which politics domain mapped with are marriage, war, weather, finalcial transactioon, battle, and journey.

WAR metaphor is one of the most common metaphors found in the political discourse [7, pp. 110-118], [5, pp. 397402], [6, pp. 21-26], [8, pp. 61-81]. Through WAR metaphor, people experience war in political discourse. People are familiar with war even though not all people directly experience it. Almost countries in the world led war, but today people experience war through war documentation such as history books and movies. Therefore, war remains rooted in people's mind. In other word, people cognitively understood and experienced war eventhough they do not directly experience it. Since it is deeply embedded in people's mind, a huge amount of WAR metaphors is used in various discourses, beside political discourse.

\section{Metaphor Translation Strategy}

For years, translation has played a functional role in breaking the language barriers and allowing people to globally 
exchange the information. The practice of translation has existed for thousand years, although the translation study is rather new than any other studies. Conceptual metaphor is one language aspect which is largely studied in the translation. From several researches which investigated the translation of conceptual metaphor, there are some different strategies which translators use in translating metaphors. Newmark [2, pp. 106113] introduces seven strategies to translate metaphor: (1) reproducing the same image in the $\mathrm{TL}$, (2) replacing the image in the SL with a standard TL image which does not clash with the TL culture if there is no exact correspondent image between SL and TL, (3) translating metaphor by simile, retaining the image, (4) translating metaphor by simile by adding sense or occasionally metaphor with addition of sense, (5) Conversing metaphor to its sense, (6) Deleting metaphor if it is redundant or serves no practical purposes, and (7) translating the metaphor by the same metaphor combined with sense. The addition of a gloss or an explanation by the translator is to ensure that the metaphor will be understood.

Zheng [3, pp. 132-137] hold that conceptual metaphor is universal so that metaphor can be translated by using literal translation. He Time is money', 'Market movement is physical movement', and 'A backward market is a disaster' exist in some languages including English and Chinese. Safarnejad, Imran-Ho-Abdullah, and Awal [9, p. 195] conclude some translation strategies of metaphor: (1) providing a different metaphor in the target text, (2) omitting the metaphor in the target text, (3) providing the same metaphor in the target text, (4) providing a literal paraphrase of the metaphor in the target text, and (5) providing a metaphor with additional information in the target text.

\section{RESEARCH MEthodOLOGY}

The objective of this study was to identify WAR metaphors in Indonesian political discourse and their translation into English. The data were collected from weekly Tempo Megazine during January to March 2018. Tempo Magazine is separately published in two language versions, Indonesia and English. Majalah Tempo as Indonesian version was used as the source language and Tempo English as English version was used as the target language. There were 29 articles collected from the megazines covering the 171 simultaneous regional head elections of 2018 and general parliamentary and presidential elections of 2019. Metaphor Identification Procedure (MIP) was implemented to identify the WAR metaphor in the discourse. War lexicons were defined as the data when a contrast found between the basic meaning and the contextual meaning. Therefore, monolingual dictionaries of Indonesia and English became the main tools during the metaphor identification. Futhermore, the conceptual mappings beetwen war and politics were determined through an analysis on the basic meaning and contextual meaning which simultaneously demonstrated the hid and highlighted aspects drawn by the mappings. At last, the translation of the WAR metaphor was analyzed to examine how the metaphors were translated into English. The metaphor translation strategy summed by Safarnejad et al [9] from several metaphor translation strategy proposed by several different scholars.

\section{RESULT AND DISCUSSION}

Through applying MIP, this study found 39 war lexical items which were used in the political discourse with total 239 occurances as in the following lists.

\begin{abstract}
Jago (13), tarung (16), perang (1), kuat (14), bidik (2), ancam (3), maneuver (2), lawan (10), survive (2), kubu (11), sandera (1), kalah (29), serang (2), menang (35), strategi (9), panglima (1), takluk (1), jaga (8), basis (3), gerilya (3), kuasa (18), markas (5), juang (2), tantang (2), fight (1), mati (3), battleground (1), taktik (1), infanteri (1), rebut (7), konflik (6), siasat (2), peluru (1), boomerang (1), incar (1), tombak (1), makar (3), booming (1), bahaya (1), medan (1), seteru (2), berondong (1), gugur (1), gencar (1), cedera (1), tangkis (1), todong (2), selamat (2), korban (1)
\end{abstract}

All the lemmas above include their lexemes which were also metaphorical to the context of politics, e.g jago, jagoan, menjagokan, dijagokan, jagoannya, and jagokan. The lexical items of WAR metaphor demonstrate a series of conceptual mapping between war and politics. WAR metaphor in the discourse was structured by a cross-mapping between war as the source domain and politics as target domain. The major mapping of the two conceptual domains can be seen in table below.

TABLE II. CONCEPTUAL MAPPING OF METAHOR POLITICS IS WAR

\begin{tabular}{|l|l|}
\hline $\begin{array}{c}\text { Source Domain } \\
\text { (War) }\end{array}$ & \multicolumn{1}{c|}{$\begin{array}{c}\text { Target Domain } \\
\text { (Politics) }\end{array}$} \\
\hline Parties of war & Political parties \\
\hline Soldier & Politicians as candidate of election \\
\hline War strategy & Campaign strategy \\
\hline Battleground & Political elections \\
\hline Target & Power \\
\hline Opponent & Other parties \\
\hline Alliance & Coalition \\
\hline Weapon & Votes \\
\hline
\end{tabular}

The conceptual mappings above clearly show how the politics was conceptualized by the concept of war. Regional head election of 2018 and general parliamentary presidential election of 2019 were likened as a battlefield where political elections presented as physical fighting among politicians or political parties. This conceptual mapping denotes that WAR metaphor in political discourse highlights politics as a battlefield for fighting for power and hides that politics goal should be for contributing in providing political ideas for people welfare and prosperity. In this study, the strategies used in the metaphor translation were also analyzed. The result of analysis of metaphor translation strategy can be seen in the table below. 
TABLE III. RESUlt OF TRANSLATION STRATEGy ANALYSIS

\begin{tabular}{|l|c|c|}
\hline \multicolumn{1}{|c|}{ Translation Strategy } & Frequency & $\begin{array}{c}\text { Percentage } \\
\text { (\%) }\end{array}$ \\
\hline $\begin{array}{l}\text { Providing the same metaphor in the } \\
\text { target text }\end{array}$ & 180 & 68.7 \\
\hline $\begin{array}{l}\text { Providing a different metaphor in } \\
\text { the target text }\end{array}$ & 30 & 11.5 \\
\hline $\begin{array}{l}\text { Providing a literal paraphrase of the } \\
\text { metaphor in the target text }\end{array}$ & 43 & 16.4 \\
\hline $\begin{array}{l}\text { Omitting the metaphor in the target } \\
\text { text }\end{array}$ & 9 & 3.4 \\
\hline
\end{tabular}

The table shows that four strategies were used to translate the WAR metaphor in political discourse from Indonesia into English. From 239 metaphorical expression, 162 (67.8\%) were translated by providing the same metaphor, 40 (16.7\%) were translated by providing a literal paraphrase, 29 (12.1\%) were translated by providing a different metaphor, and 8 (3.4\%) were translated by omitting the metaphor. Meanwhile, no metaphor was translated by providing a metaphor with addition of the metaphor sense.

\section{Discussion}

The objective of this study was to identify WAR metaphors in Indonesian political discourse and their translation into English. Based on the result of this study, WAR metaphor is positively pervasive in Indonesian political discourse. There were 39 war lexical items which were metaphorical to the context of politics with total 239 occurrences. Not all war lexical items were categorized as metaphor because they were not metaphorical to the given context, e.g. perang in phrase Perang Dunia II.

Not everyone experiences the war directly, but based on the history, most countries in the world had experienced the war. The war is perceived as a valuable history to memorize hence that experience has been documented in various means and media. Through the documentation, people who do not experience war directly can recognize a wide variety of war components such as opponent, soldier, weapon, truce, and strategy. So it is reasonable that WAR metaphor is strongly rooted in human nature. WAR metaphor is pervasive in the language, thought, and action. It is proved by the use of WAR metaphor in many different patterns of discourse.

According to the findings of war lexical items or metaphorical expressions, the conceptual metaphor found in the discourse is POLITICAL ELECTION IS A BATTLEGROUND. The upcoming regional head elections that will be held simultaneously on June 2018 in 171 locations in Indonesia and parliamentary and presidential election of 2019 were likened as war between nations with the political candidates as the soldiers. Politic and war metaphor is closely related. Numerous studies of WAR metaphor in political discourse found that WAR metaphor is one of the most powerful tools to achieve several language functions, especially persuasive function.

This study found various conceptual mappings between war and politics. The mapping demonstrates that WAR metaphor in the political discourse creates the presentation of political elections as a battleground where the soldiers fight for power. The political candidates play the role of soldiers and the party is their nation which is possible to do alliance with in term of political coalition. The WAR metaphor in the discourse views the political elections as a physical fighting between politicians to achieve political goals of individual or parties. Through the analysis, it was found that indeed many aspects of war closely similar with the concept of war. Politics consists of numerous abstract and complicated concept which are not understood by all people. Therefore, the writer intended to help the reader to make concrete the abstract and complicated concept of metaphor through applying WAR metaphor since it is universal for most people cognitive.Thus, the reader of the political news will be easily to comprehend the concept of political activities, general election for these cases.

There should be consequences of decision for applying the $W A R$ metaphor in news of politics. As a positive consequence, $W A R$ metaphor creates strong, brave and inspirational image of the political candidates. But the negative consequence, $W A R$ metaphor in the discourse allows the political candidate to perform any behavior to achieve political goal, including uncivilized, frontal, and manipulative behaviors.

Another finding which is also critical to be highlighted is that 162 of 239 total war expressions were translated by providing the same metaphor in the target language. War indeed is a universal experience which is similarly experienced by people across the countries in world so that the war concept can be also understood by people over the countries. Translation by providing WAR metaphor in English will not confuse the readers.

The strategy was implemented in two different ways: (1) providing the same domain and the same expression and (2) providing the same domain with different expression.

- $\quad H a r u s$ diakui, hasil pertarungan dalam pilkada akan berpengaruh terhadap elektabilitas partai politik dan calon presiden yang akan diusung pada Pemilu 2019.

The results of the battles in the regional head elections, it must be acknowledged, will influence the electability of political parties and their presidential candidates in the 2019 General Elections.

- Jika PDI Perjuangan tak bisa menaklukkannya, Jokowi dipastikan akan berat menempuh pemilihan presiden 2019.

If the PDI-P fails to secure victories in these regions, Jokowi will be sure to face a challenging presidential election in 2019.

In the first sentence, pertarungan is translated battle in English. Pertarungan and battle are from the same domain (war) and same expression to refer to physical fighting between armed forces. Meanwhile the second sentence, menaklukkannya is translated secure a victory in English. This is an example of translation by providing the same domain with different expression. Menaklukkan refers to conquer or overcome and take control of a place or people, while secure victories refers to gain victory or to win.

The second strategy is transation by providing a different metaphor in target language.

- Selain karena mahar, Sudrajat sangsi maju ke pertarungan kursi gubernur karena namanya sudah lama tak akrab di telinga masyarakat. 
In addition to the issue of advance campaign funds, Sudrajat hesitated to enter the race for governor because he has not been in the public spotlight for some time.

- $\quad$ Sebelum di Jawa Tengah, nama Budi Waseso digadang-gadang bakal bertarung di Sumatera Utara.

Budi Waseso was also projected to run as a candidate for governor in North Sumatera.

The strategy was determined when WAR metaphor in source text is translated by providing a different source domain in the target text. The source domain of the two source sentences is from war domain but the two sentences are translated into English by providing two different source domains. The source text used WAR metaphor which liken the political election as a physical fighting between armed forces. in the target text the two war expressions were translated by providing source domain of race in first sentence and source domain of sport in the second langguage. In the first sentence, political election was likened as a race or competition between runners, horses, vehicles, etc. to see which is the fastest in covering a set course. While in the second sentence, political election was likened as runners competition.

The third strategy is translation by providing the literal paraphrase in the target text.

- $\quad$ Agus menjadi populer setelah ikut pemilihan Gubernur Jakarta tahun lalu dan kalah.

Agus became popular after running in Jakarta's gubernatorial election last year, although he was not elected.

- Selain menggalang pembentukan kelompok relawan, Moeldoko rutin mengunjungi daerah yang pada 2014 merupakan medan kekalahan Jokowi.

In addition to raising support to form volunteer groups, Moeldoko routinely visits areas where Jokowi received fewer votes in the 2014 election.

The war expressions in the source text were translated by providing the contextual meaning. In the first sentence, kalah means lose was paraphrased to was not elected which is the contextual meaning of kalah. In the second sentence, kekalahan was paraphrased to received fewer votes as the contextual meaning of the kekalahan.

The last strategy used in the translation of IndonesianEnglish political discourse is translation by omitting the metaphor.

- $\quad$ Di partai beringin, Tommy sempat menjajal bertarung merebut kursi ketua umum dalam Musyawarah Nasional Golkar 2009 di Riau. Tommy once competed to become Golkar general chair, in the Golkar National Convention in 2009 in Riau, running against Aburizal Bakrie, Surya Paloh, and Yuddy Chrisnandi.

- $\quad$ Membesarkan partai politik tidak bisa hanya dilakukan secara instan dengan berebut tokoh populer dalam ajang pilkada, tapi harus dilandasi visi atau ideologi yang menyentuh kepentingan publik. Developing a political party cannot be done instantly- simply by fighting to get popular figures to represent it in elections- but instead should have been based on a vision or ideology that affect the public interest.
In the sentences above, the WAR metaphor in source text was not translated into English. The translation strategy omits the metaphorical expression in the source text and does not translate it in target text, even its senses. Nevertheless, the strategy does not make wrong translation even though the meaning of the source text and target text are not precisely equivalent.

\section{CONCLUSION}

The primary result of this study is that WAR metaphor positively pervasive in Indonesian political discourse. The cross-mappings between war and politics were soldier to political candidate, war strategy to campaign strategy, battleground to political elections, target to power, alliance to parties coalition, and weapon to votes. This conceptual mapping denotes that WAR metaphor in political discourse highlights politics a as a battleground for fighting for power and hides that politics goal should be for contributing in providing political ideas for people welfare and prosperity. Futhhermore, there were four strategies used in the IndonesiaEnglish translation of the political discourse namely providing the same metaphor in target text, providing a different metaphor in target text, providing literal paraphrase in target text, and omitting the providing the same metaphor in target text. The dominant strategy is translation by providing the same metaphor in target text. War is a universal experience hence translating war metaphhor directly is acceptable in other languages, including in English.

\section{REFERENCES}

[1] G. Lakoff and M. Johnson, Metaphors we live by. Chicago: University of Chicago Press, 1980.

[2] P. Newmark, “A Textbook of Translation,”London: Prentice Hall, 1988.

[3] J. Zheng, "Translation Metaphor in Business English from a Cognitive Perspective,” Int. J. of Engl. Linguist., vol. 5, no. 2, pp. 133-138, 2015.

[4] Pragglejas Group, "MIP: A Method for identifying metaphorically used words in discourse,” Metaph. and Symb., vol 22, no. 1, pp. 1-39, 2007.

[5] L. Xu, "Metaphor in Action in Political Discourse," Int. Conf. on Econ., Soc. Sci., Art., Edu., and Manage. Eng., pp. 397-402, 2015.

[6] R.F. Otieno, F.R. Owino, and J.M Attayang, "Metaphors in political discourse: A review of selected studies,” Int. J. of Eng. and Lit., vol. 7, no. 2, pp. 21-26, 2016.

[7] L. Arcimaviciene, "Morality Models Through Metaphors in Public Discourse: A Cross-Linguistic Analysis,” Ph.D. disertation, Vilmus Univ., 2010.

[8] D. B. Lenard and C. Nevena, "The Analysis of Metaphors and Metonymies in Political Speeches - A Case Study of the Former Croatian Prime Minister Ivo Sanader,” ELR J., pp. 61-81, 2017.

[9] F. Safarnejad, Imran-Ho-Abdullah, and N.M. Awal, "Rendering happiness Metaphors: A Cognitive Analysis from Persinen into English,” J. of Lang. Stud., vol. 13, no. 2, pp. 193-205, 2013. 